\title{
Reactive Oxygen Species Downregulate Transient Receptor Potential Melastatin 6 Expression Mediated by the Elevation of miR-24-3p in Renal Tubular Epithelial Cells
}

\author{
Chieko Hirota ${ }^{1}$, Yui Takashina ${ }^{1}$, Yuta Yoshino ${ }^{1}$, Hajime Hasegawa ${ }^{2}$ (D) Ema Okamoto ${ }^{1}$, Toshiyuki Matsunaga ${ }^{3}$ \\ and Akira Ikari $1, * \mathbb{D}$ \\ 1 Laboratory of Biochemistry, Department of Biopharmaceutical Sciences, Gifu Pharmaceutical University, \\ Gifu 501-1196, Japan; 165067@gifu-pu.ac.jp (C.H.); 145037@gifu-pu.ac.jp (Y.T.); \\ yoshino-yu@gifu-pu.ac.jp (Y.Y.); 185020@gifu-pu.ac.jp (E.O.) \\ 2 Saitama Medical Center, Department of Nephrology and Hypertension, Saitama Medical University, \\ Saitama 350-8550, Japan; hase2126@saitama-med.ac.jp \\ 3 Education Center of Green Pharmaceutical Sciences, Gifu Pharmaceutical University, Gifu 502-8585, Japan; \\ matsunagat@gifu-pu.ac.jp \\ * Correspondence: ikari@gifu-pu.ac.jp; Tel./Fax: +81-58-230-8124
}

\section{check for} updates

Citation: Hirota, C.; Takashina, Y.; Yoshino, Y.; Hasegawa, H.; Okamoto, E.; Matsunaga, T.; Ikari, A. Reactive Oxygen Species Downregulate Transient Receptor Potential

Melastatin 6 Expression Mediated by the Elevation of miR-24-3p in Renal Tubular Epithelial Cells. Cells 2021, 10, 1893. https://doi.org/10.3390/ cells10081893

Academic Editor: Laura Lasagni

Received: 9 July 2021

Accepted: 24 July 2021

Published: 26 July 2021

Publisher's Note: MDPI stays neutral with regard to jurisdictional claims in published maps and institutional affiliations.

Copyright: (c) 2021 by the authors. Licensee MDPI, Basel, Switzerland. This article is an open access article distributed under the terms and conditions of the Creative Commons Attribution (CC BY) license (https:// creativecommons.org/licenses/by/ $4.0 /)$.
Abstract: Background: A low level of serum magnesium ion $\left(\mathrm{Mg}^{2+}\right)$ is associated with type 2 diabetes mellitus (T2D). However, the molecular mechanism of $\mathrm{Mg}^{2+}$ deficiency has not been fully clarified. The current study sought to assesses the effect of reactive oxygen species on the expression of $\mathrm{Mg}^{2+}$ channels and miRNA. Methods: The expression of $\mathrm{Mg}^{2+}$ channels and miRNA were examined by real-time polymerase chain reaction. Intracellular $\mathrm{Mg}^{2+}$ concentration was measured by Magnesium Green fluorescence measurement. Results: The mRNA level of transient receptor potential melastatin 6 (TRPM6), which functions as $\mathrm{Mg}^{2+}$ influx channel in the distal convoluted tubule (DCT) of the kidney, was decreased by glycated albumin (GA), but not by insulin in rat renal tubule-derived NRK-52E cells. The mRNA levels of TRPM7, a homologue of TRPM6, and CNNM2, a $\mathrm{Mg}^{2+}$ efflux transporter located at the basolateral membrane of DCT, were changed by neither GA nor insulin. The generation of reactive oxygen species (ROS) was increased by GA. Hydrogen peroxide $\left(\mathrm{H}_{2} \mathrm{O}_{2}\right)$ dose-dependently decreased TRPM6 mRNA, but it inversely increased the reporter activity of TRPM6. $\mathrm{H}_{2} \mathrm{O}_{2}$ accelerated the degradation of TRPM6 mRNA in actinomycin D assay without affecting TRPM7 and CNNM2 mRNA expressions. Nine miRNAs were considered as candidates for the regulator of stability of TRPM6 mRNA. Among them, miR-24-3p expression was increased by $\mathrm{H}_{2} \mathrm{O}_{2}$. The $\mathrm{H}_{2} \mathrm{O}_{2}$-induced reduction of TRPM6 mRNA was rescued by miR-24-3p siRNA. Magnesium Green fluorescence measurement showed that $\mathrm{Mg}^{2+}$ influx is suppressed by $\mathrm{H}_{2} \mathrm{O}_{2}$, which was rescued by an antioxidant and miR-24-3p siRNA. Conclusions: We suggest that GA decreases TRPM6 expression mediated by the elevation of ROS and miR-24-3p in renal tubular epithelial cells of T2D.

Keywords: type 2 diabetes mellites; glycated albumin; hypomagnesemia; miRNA; TRPM6

\section{Introduction}

The body content of magnesium is controlled by the absorption in the intestine and reabsorption in the kidney. The concentration of serum magnesium ion $\left(\mathrm{Mg}^{2+}\right)$ is maintained within narrow range from 0.75 to $0.95 \mathrm{mmol} / \mathrm{L}$ under physiological conditions [1]. Approximately $80 \%$ of the total serum $\mathrm{Mg}^{2+}$ is filtered in the glomeruli of kidney with more than $95 \%$ is reabsorbed along the nephron, and only $5 \%$ is excreted into the urine [2]. The majority of filtrated $\mathrm{Mg}^{2+}$ is reabsorbed via a paracellular route in the thick ascending limb of the Henle's loop. The reabsorption rate is only $5 \%$ in the distal convoluted tubule (DCT), but this process plays an important role in the fine-tuning of urinary $\mathrm{Mg}^{2+}$ excretion. Transient receptor potential melastatin 6 (TRPM6) is located at the apical membrane of DCT, a main site of active renal $\mathrm{Mg}^{2+}$ reabsorption [3], and may facilitate $\mathrm{Mg}^{2+}$ influx 
from the lumen to the cells. CNNM2, $\mathrm{a} \mathrm{Mg}^{2+}$ efflux transporter located at the basolateral membrane, is considered to transport $\mathrm{Mg}^{2+}$ from the cells to the blood in the DCT, but it is controversial $[4,5]$.

Many investigators reported that $\mathrm{Mg}^{2+}$ deficiency may be one of the important risk factors for lifestyle-related diseases such as type 2 diabetes mellitus (T2D), hypertension, and hyperlipidemia [6,7]. High $\mathrm{Mg}^{2+}$ intake is associated with a reduced incidence of T2D in women [8]. T2D patients usually have impaired sensitivity to insulin, so-called insulin resistance, and often develop a hyperglycemic condition and nephropathy [9]. A clinical randomized double-blind placebo-controlled trial shows the administration of $\mathrm{Mg}^{2+}$ supplementation improves insulin resistance and metabolic control in T2D patients [10]. Thus, there is no doubt about the correlation between hypomagnesemia and T2D. Takayanagi et al. [11] reported that the reduction of TRPM6 expression in obese T2D rats may cause hypermagnesiuria and nephropathy. However, it is unknown how TRPM6 expression is downregulated in T2D.

Despite the importance of TRPM6 in the maintenance of $\mathrm{Mg}^{2+}$ homeostasis, the regulatory mechanism of TRPM6 gene is mostly unknown. So far, we revealed that epidermal growth factor (EGF) increases the transcriptional activity of TRPM6 mediated through the activation of a mitogen-activated protein kinase kinase (MEK) and extracellular signalregulated kinase (ERK), so-called MEK/ERK signaling pathway using rat renal tubular NRK-52E and human embryonic kidney 293 (HEK293) cells [12,13]. Renal $\mathrm{Mg}^{2+}$ wasting is an undesirable side effect during anticancer therapy. EGF receptor (EGFR) tyrosine kinase inhibitors and EGFR-targeting monoclonal antibody may develop hypomagnesemia mediated through the inhibition of MEK/ERK pathway and the reduction of TRPM6 expression [14]. In addition, cisplatin, a platinum anticancer drug, decreases the mRNA levels of EGF and TRPM6 in the rat kidney [15]. Therefore, the MEK/ERK pathway may play a crucial role in the regulation of TRPM6 mRNA expression and $\mathrm{Mg}^{2+}$ homeostasis under physiological conditions.

The production of advanced glycation end-products (AGEs) are implicated in the development of diabetic nephropathy [16]. The activity of TRPM6 channel has been reported to be inhibited by hydrogen peroxide $\left(\mathrm{H}_{2} \mathrm{O}_{2}\right)$ in HEK293 transfected with human TPRM6 [17]. In contrast, the effect of oxidative stress on TRPM6 expression remains to be elucidated. In the present study, we found that TRPM6 expression is decreased by glycated albumin (GA) and $\mathrm{H}_{2} \mathrm{O}_{2}$ in NRK-52E cells. To clarify the regulatory mechanism of TRPM6 expression, transcriptional activity, mRNA stability, and $\mathrm{Mg}^{2+}$ flux of TRPM6 were investigated using the dual-luciferase reporter assay, actinomycin D assay, and fluorescence assay, respectively.

\section{Materials and Methods}

\subsection{Materials}

GA, insulin, and N-acetyl-L-cysteine (NAC) were obtained from Sigma-Aldrich (St. Louis, MO, USA) and dissolved in water. $2^{\prime}, 7^{\prime}$-dichlorodihydrofluorescein diacetate $\left(\mathrm{H}_{2}\right.$ DCFDA) and Mag-Fura-2 AM were from Thermo Fisher Scientific (Waltham, MA, USA).

\subsection{Cell Culture and Transfection}

Normal rat renal tubule-derived NRK-52E cells (IFO50480) were purchased from Japanese Collection of Research Biosciences (Osaka, Japan). So far, we reported that mRNAs and proteins of TRPM6, TRPM7, and CNNM2 were detected in NRK-52E cells by real time PCR and Western blotting, respectively [18]. The cells were cultured in Dulbecco's modified Eagle's medium supplemented with 5\% fetal bovine serum as described previously [13]. Universal negative control and miR-24-3p siRNAs (Sigma-Aldrich) were transfected with Lipofectamine RNAiMAX (Thermo Fisher) according to manufacturer's instructions. 


\subsection{Isolation of Total RNA and Quantification of $m R N A$}

Total RNA was isolated form NRK-52E cells with TRI reagent (Molecular Research Center, Cincinnati, OH, USA) and reverse transcriptional reaction was done using ReverTra Ace qPCR RT Kit (Toyobo Life Science, Osaka, Japan). For the assay of miRNA, cDNA was prepared using Mir-X miRNA First-Strand Synthesis Kit (Takara Bio, Shiga, Japan). Quantitative real-time polymerase chain reaction (PCR) were done using a, Eco Real-Time PCR system (AS One, Osaka, Japan) with a THUNDERBIRD SYBR qPCR Mix (Toyobo Life Science). Primer pairs used for PCR are shown in Table 1. After subtracting the threshold cycle $(\mathrm{Ct})$ obtained for $\beta$-actin, the relative change of mRNA expression was calculated by $\Delta \Delta \mathrm{Ct}$ method.

Table 1. Primer pairs for real-time PCR.

\begin{tabular}{|c|c|c|}
\hline Genes & Direction & Sequence $\left(5^{\prime} \rightarrow 3^{\prime}\right)$ \\
\hline \multirow{2}{*}{ TRPM6 } & Sense & CTTCTTGGGATACCAAATCAG \\
\hline & Antisense & GAAACTTTTCCTAGTGTAGCTG \\
\hline \multirow{2}{*}{ TRPM7 } & Sense & AACCAACACTCTGGAAGAGATCA \\
\hline & Antisense & TCAGTCAAGTTTTCTCCCACAC \\
\hline \multirow{2}{*}{ CNNM2 } & Sense & AАСАССАТСТТССТСАССАAGT \\
\hline & Antisense & TCAGCTCTTCCTTAACGAGGTC \\
\hline \multirow{2}{*}{$\beta$-Actin } & Sense & CCAACCGTGAAAAGATGACC \\
\hline & Antisense & CCAGAGGCATACAGGGACAG \\
\hline$m i R-24-3 p$ & Sense & TGGCTCAGTTCAGCAGGAAC \\
\hline let-7d-5p & Sense & AGAGGTAGTAGGTTGCATAG \\
\hline$m i R-26 a-5 p$ & Sense & TTCAAGTAATCCAGGATAGG \\
\hline$m i R-140-3 p$ & Sense & ATGGTGTCTTTAGTACCGTC \\
\hline$m i R-143-3 p$ & Sense & TCTCTACTCCGAGTCTCCCA \\
\hline$m i R-34 a$ & Sense & CCCGTCACTCTCTACTCCGA \\
\hline$m i R-218-5 p$ & Sense & AACACGAAAACAAAGTAAGT \\
\hline$m i R-128-3 p$ & Sense & GGTGTCACAAAGACTCGAAT \\
\hline miR-193-3p & Sense & CTGACCGGTTCCTCTTGTCT \\
\hline
\end{tabular}

\subsection{Preparation of Cytoplasmic Extracts and Western Blotting}

The preparation of cytoplasmic extracts and sodium dodecyl sulfate polyacrylamide gel electrophoresis were carried out as described previously [13]. After blotting samples to poly (vinylidene fluoride) membrane, the membrane was blocked with a $2 \%$ bovine serum albumin for $30 \mathrm{~min}$. Then, the membrane was incubated with anti-p-ERK and anti-ERK antibodies (1:1000 dilution) at $4{ }^{\circ} \mathrm{C}$ for $16 \mathrm{~h}$, followed by a peroxidase-conjugated secondary antibody (1:3000 dilution) at room temperature for $1.5 \mathrm{~h}$. Finally, the chemiluminescence of horseradish peroxidase was detected using a C-DiGit Blot Scanner (LI-COR Biotechnology, Lincoln, NE, USA). The band density was quantified using ImageJ software (National Institute of Health software). $\beta$-actin was used for normalization.

\subsection{Luciferase Reporter Assay}

So far, we constructed the luciferase reporter vector containing promoter of the human TRPM6 gene [19]. The reporter vectors of mock and TRPM6 were transfected into the cells with HilyMax (Dojindo Laboratories, Kumamoto, Japan). A pRL-TK vector (Promega, Madison, WI, USA), which contains Renilla luciferase gene under the herpes simplex virus thymidine kinase promoter, was used for normalizing transfection efficiency. The Dual-Glo 
Luciferase Assay System (Promega) was used to explore the activities of firefly and renilla luciferases.

\section{6. $\mathrm{Mg}^{2+}$ Influx Assay}

The change in intracellular free $\mathrm{Mg}^{2+}$ concentration $\left(\left[\mathrm{Mg}^{2+}\right]_{\mathrm{i}}\right)$ was measured with a $\mathrm{Mg}^{2+}$-sensitive fluorescent dye, Magnesium Green AM (Thermo Fisher Scientific). NRK$52 \mathrm{E}$ cells cultured on 96 well plates were loaded with Hank's Balanced salt solution (HBSS) containing $2 \mu \mathrm{M}$ Magnesium Green $\mathrm{AM}$ at $37^{\circ} \mathrm{C}$ for $30 \mathrm{~min}$, followed by washing with dyefree HBSS twice. After replacement of extracellular solution from nominally $\mathrm{MgCl}_{2}$-free HBSS to $5 \mathrm{mM} \mathrm{MgCl}$-containing HBSS at $0 \mathrm{~min}$, the fluorescence intensity of Magnesium Green was measured every $20 \mathrm{~s}$ at $485 \mathrm{~nm}$ (excitation)/535 nm (emission) using an Infinite F200 Pro fluorescence microplate reader (Tecan, Mannedorf, Switzerland). The change of fluorescence intensity of Magnesium Green was represented as a percentage at $0 \mathrm{~min}$.

\subsection{Reactive Oxygen Species (ROS) Generation}

$\mathrm{H}_{2}$ DCFDA, a marker of a wide spectrum of ROS, was used for the measurement of generation of intracellular ROS. NRK-52E cells were incubated in the presence or absence of insulin and $500 \mu \mathrm{g} / \mathrm{mL}$ GA for $1 \mathrm{~h}$. Then, the cells were incubated with $10 \mu \mathrm{M} \mathrm{H}_{2}$ DCFDA at $37^{\circ} \mathrm{C}$ for $30 \mathrm{~min}$. After washing with HBSS twice, the fluorescence intensity of DCF was measured by fluorescence microplate reader.

\subsection{Statistical Analysis}

All data are presented as mean \pm standard error using KaleidaGraph software (Synergy Software, Reading, PA, USA). Statistical significance was evaluated by a one-way ANOVA analysis for multiple comparison between groups. Statistical comparisons between two groups were conducted by a Student's $t$-test. A $p$ value of $<0.05$ was taken as significant.

\section{Results and Discussion}

\subsection{Decrease in TRPM6 Expression in NRK-52E Cells by GA}

TRPM6 and CNNM2 are localized at the apical and basolateral membranes of DCT, respectively, and may be involved in the transcellular reabsorption of $\mathrm{Mg}^{2+}[4,20]$. In contrast, TRPM7, a close homologue of TRPM6, is ubiquitously found in most tissues and involved in the regulation of $\mathrm{Mg}^{2+}$ homeostasis [21]. In a nested case-control study of the Women's Health Study, two common non-synonymous variants of TRPM6 coding region, I1393V and K1584E polymorphisms, confer susceptibility to T2D in women with low $\mathrm{Mg}^{2+}$ intake [22]. The abnormal expression of TRPM6 may be involved in T2D, but the regulatory mechanism of TRPM6 expression is not fully understood. Lepr fa ${ }^{f a}$ rats show hyperinsulinemia and staining of AGEs in the renal cortex [23]. Therefore, we investigated the effects of insulin and GA on TRPM6 expression using NRK-52E cells because TRPM6 is functionally expressed in the cells [12]. The mRNA level of TRPM6 was significantly decreased by GA, but not by insulin (Figure 1). In contrast, neither those of TRPM7 nor CNNM2 were changed by GA nor insulin. These results suggest that the elevation of GA concentration induces the decrease in TRPM6 expression in the kidney of T2D patients. Insulin stimulates TRPM6 activity mediated by increased phosphorylation of intracellular signaling cascade including phosphatidylinositol 3-kinase, Akt, and Rac1 [24], but $\mathrm{Mg}^{2+}$ reabsorption may be diminished by the reduction of TRPM6 expression. The association of $\mathrm{Mg}^{2+}$ deficiency and insulin resistance has been reported in obese children [25] and in normal human subjects with low $\mathrm{Mg}^{2+}$ diets [26]. Disruption of $\mathrm{Mg}^{2+}$ homeostasis caused by reduction of TRPM6 expression may be involved in the exacerbation of glucose tolerance and insulin resistance. 


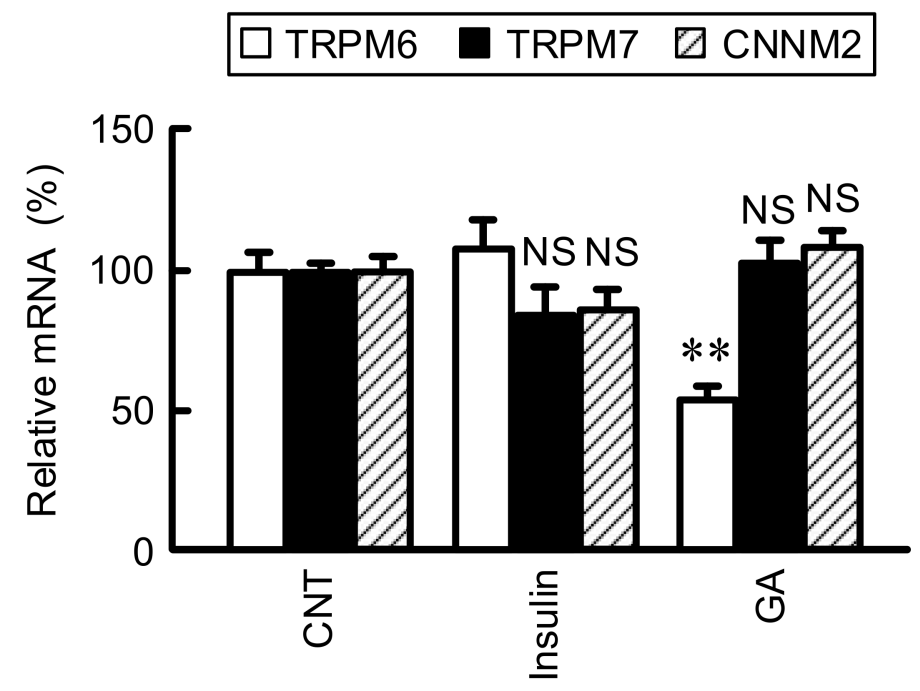

Figure 1. Effects of insulin and GA on the expression of $\mathrm{Mg}^{2+}$ transporters. The cDNA was prepared from total RNA of NRK-52E cells treated with vehicle (CNT), $10 \mathrm{nM}$ insulin, or $500 \mu \mathrm{g} / \mathrm{mL}$ GA for $6 \mathrm{~h}$. Real time PCR was carried out by primers for TRPM6, TRPM7, CNNM2, and $\beta$-actin. The expression levels of TRPM6, TRPM7, and CNNM2 were normalized by $\beta$-actin, and were represented as percentage of CNT. $n=3-4 .{ }^{* *} p<0.01$ and ${ }^{\mathrm{NS}} p>0.05$ compared with CNT.

\subsection{Involvement of ROS in the GA-Induced Reduction of TRPM6 Expression}

AGEs have been reported to induce injury of renal tubular epithelial cells mediated by generation of ROS [27]. To clarify the involvement of ROS, we monitored intracellular ROS content using a fluorescent probe $\mathrm{H}_{2}$ DCFDA. The fluorescence intensity of DCF was significantly increased by GA, but not by insulin (Figure 2A). The GA-induced reduction of TRPM6 expression was inhibited by NAC (Figure 2B). AGEs bind to the receptor of AGEs, leading to activation of its down-stream signaling and oxidative stress responses in renal cells [28]. We suggest that GA decreases TRPM6 expression mediated by the generation of ROS. To substantiate the involvement of ROS, the effect of hydrogen peroxide $\left(\mathrm{H}_{2} \mathrm{O}_{2}\right)$, a ROS generator, on TRPM6, TRPM7, and CNNM2 expressions was investigated by real-time PCR. The mRNA level of TRPM6 was concentration-dependently decreased by $\mathrm{H}_{2} \mathrm{O}_{2}$ (Figure 2C). In contrast, the mRNA levels of TRPM7 and CNNM2 were not significantly changed. The mRNA expression of TRPM6 is upregulated by an activated MEK/ERK pathway in NRK-52E cells [13]. The involvement of inhibition of MEK/ERK pathway is hypothesized in the downregulation of TRPM6 expression by ROS. However, $\mathrm{H}_{2} \mathrm{O}_{2}$ increased the level of p-ERK without affecting total amount of ERK (Figure 2D). Furthermore, the reporter activity of TRPM6 was significantly exaggerated by $\mathrm{H}_{2} \mathrm{O}_{2}$ (Figure 2E). The p-ERK level is upregulated in the renal cortex of diabetic model mice [22]. So far, we reported that the reporter activity of TRPM6 is in proportion to the p-ERK level [18]. Therefore, there is no doubt that ROS can increase transcriptional activity of TRPM6. However, the mRNA level of TRPM6 was downregulated by $\mathrm{H}_{2} \mathrm{O}_{2}$ as shown in Figure 2C. We suggest that ROS can downregulates TRPM6 expression mediated by other mechanism, which acts more significantly than the transcriptional regulation. To clarify the hypothesis, we examined the effect of $\mathrm{H}_{2} \mathrm{O}_{2}$ on the mRNA stability of TRPM6. 


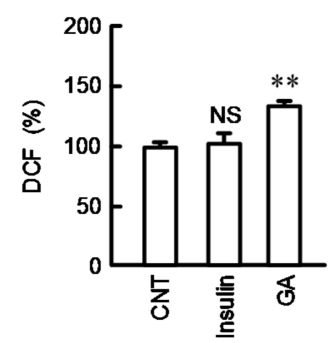

B

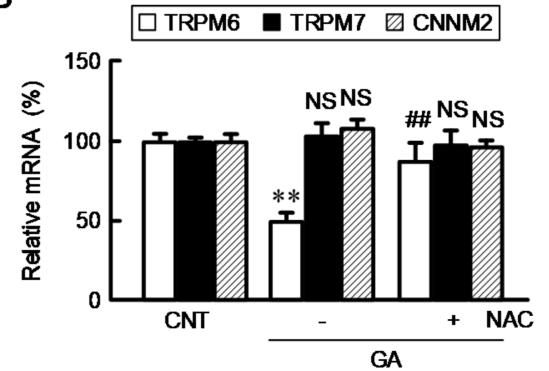

C

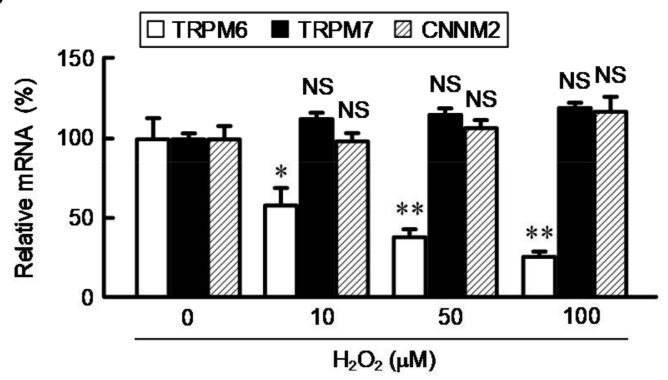

D

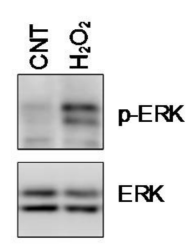

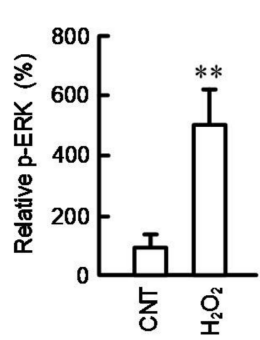

$E$
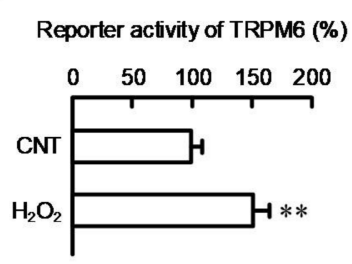

Figure 2. Effect of $\mathrm{H}_{2} \mathrm{O}_{2}$ on mRNA expression and reporter activity of TRPM6. (A) NRK-52E cells were treated with vehicle (CNT), $10 \mathrm{nM}$ insulin, and $500 \mu \mathrm{g} / \mathrm{mL}$ GA for $1 \mathrm{~h}$. The intracellular ROS contents were measured using DCF and represented as percentage of CNT. (B) Cells were treated in the presence or absence (CNT) of $500 \mu \mathrm{g} / \mathrm{mL} \mathrm{GA}$ and $2 \mathrm{mM} \mathrm{NAC}$ for $6 \mathrm{~h}$. The mRNA levels of TRPM6, TRPM7, and CNNM2 were represented as percentage of CNT. (C) Cells were treated with $\mathrm{H}_{2} \mathrm{O}_{2}$ for $6 \mathrm{~h}$ at the concentrations indicated. The mRNA levels of TRPM6, TRPM7, and CNNM2 were represented as percentage of $0 \mu \mathrm{M}$. (D) Cells were treated with vehicle (CNT) and $50 \mu \mathrm{M}$ $\mathrm{H}_{2} \mathrm{O}_{2}$ for $1 \mathrm{~h}$. The expression levels of p-ERK and ERK were measured by Western blotting and represented as percentage of CNT. (E) The reporter vector of TRPM6 was transfected into the cells using HilyMax. The transfection efficiency was corrected for by the ratio of firefly luciferase activity to Renilla luciferase activity and represented as percentage of CNT. $n=3-5 .{ }^{* *} p<0.01,{ }^{*} p<0.05$ and NS $p>0.05$ compared with CNT or $0 \mu \mathrm{M}$. ${ }^{\#} p<0.01$ compared with -NAC.

\subsection{Involvement of miR-24-3p in the ROS-Induced Reduction of TRPM6 Expression}

In the mRNA stability assay, NRK-52E cells were treated with actinomycin D to prevent mRNA transcription. The mRNA level of TRPM6 was deteriorated depending on actinomycin D-treated period, which was reinforced by $\mathrm{H}_{2} \mathrm{O}_{2}$ (Figure 3A). In contrast, those of TRPM7 and CNNM2 were unchanged by $\mathrm{H}_{2} \mathrm{O}_{2}$. The mRNA stability of various genes is regulated by miRNA, RNA-binding proteins, and long non-coding RNAs [29]. The regulatory miRNAs of TRPM6 have been predicted using miRanda database [30], suggesting that hsa-let- $7 \mathrm{~b}, 7 \mathrm{c}, 7 \mathrm{~d}, 7 \mathrm{~g}$, and $7 \mathrm{f}-1 \mathrm{can}$ bind to $3^{\prime}$-untranslated region ( $3^{\prime} \mathrm{UTR}$ ) of TRPM6 mRNA in colon adenocarcinoma. In the present study, we found other candidates including miR-24-3p, 26a-5p, 140-3p, 143-3p, 34a, 218-5p, 128-3p, 193-3p, and let-7d-5p interact with $3^{\prime}$ UTR using Target Scan Program [31]. Among them, the expression level of miR-24-3p was significantly upregulated by $\mathrm{H}_{2} \mathrm{O}_{2}$, whereas those of other miRNAs were constant or decreased (Figure 3B). Therefore, we decided to investigate the involvement of miR-24-3p. The $\mathrm{H}_{2} \mathrm{O}_{2}$-induced reduction of TRPM6 mRNA was rescued by miR-24-3p 
siRNA (Figure 3C). In contrast, the mRNA levels of TRPM7 and CNNM2 were unchanged by $\mathrm{H}_{2} \mathrm{O}_{2}$ and miR-24-3p siRNA. We suggest that miR-24-3p is a key factor in the downregulation of TRPM6 expression in the $\mathrm{H}_{2} \mathrm{O}_{2}$-treated NRK-52E cells. The downregulation of TRPM6 expression causes a tubulointerstitial nephropathy in obese T2D rats [11]. However, miR-24-3p has been reported to negatively correlate with the diabetic nephropathy progression [32]. Cell proliferation and fibrosis are inhibited by knockdown of fibroblast growth factor 11, a down-stream target of miR-24-3p. The diabetic nephropathy may not be caused by the alteration of single or few genes.

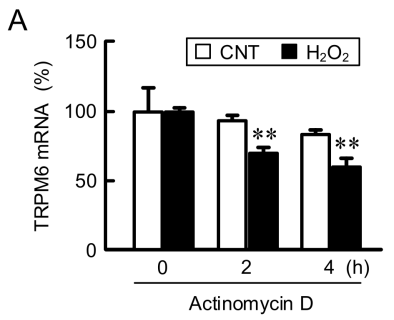

B

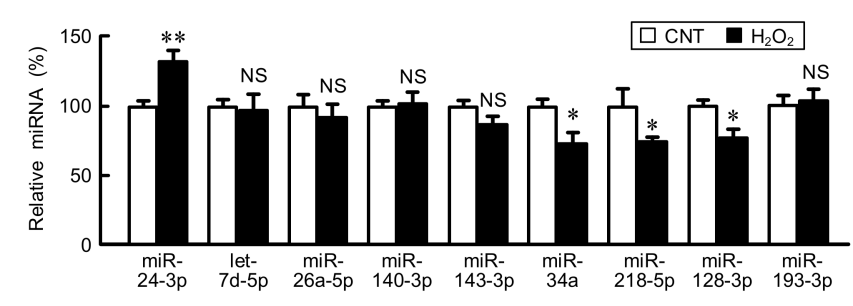

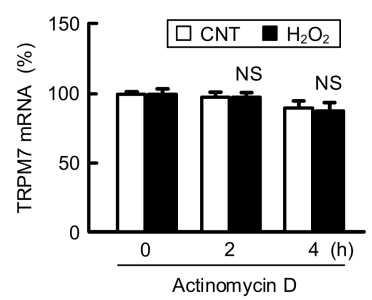

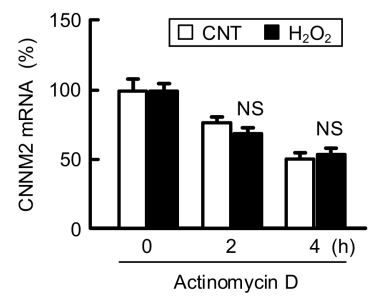

C

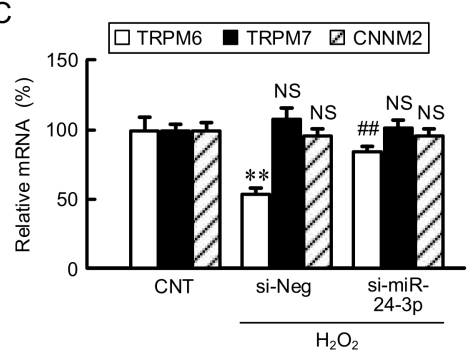

Figure 3. Involvement of miR-24-3p in the decrease in TRPM6 mRNA by $\mathrm{H}_{2} \mathrm{O}_{2}$. (A) NRK-52E cells were treated with actinomycin $\mathrm{D}$ in the presence or absence (CNT) of $\mathrm{H}_{2} \mathrm{O}_{2}$ for the periods indicated. The mRNA levels of TRPM6, TRPM7, and CNNM2 were represented as percentage of $0 \mathrm{~h}$. (B) Cells were treated in the presence or absence (CNT) of $\mathrm{H}_{2} \mathrm{O}_{2}$ for $6 \mathrm{~h}$. The miRNA levels were determined by real time PCR and compared with CNT. (C) The cells transfected with negative (si-Neg) or miR-24-3p siRNA (si-miR-24-3p) were treated with $\mathrm{H}_{2} \mathrm{O}_{2}$ for $6 \mathrm{~h}$. The mRNA levels of TRPM6, TRPM7, and CNNM2 were represented as percentage of CNT. $n=3-4$. ${ }^{* *} p<0.01,{ }^{*} p<0.05$ and ${ }^{\mathrm{NS}} p>0.05$ compared with CNT or $0 \mu \mathrm{M}$. ${ }^{\# \#} p<0.01$ compared with si-Neg.

Extracellular vesicles (EVs) contain various molecules including DNA, mRNA, miRNAs, proteins, and lipids, and are released into extracellular fluid. Urine is a highly useful specimen for biomarker discovery because it can be collected easily using non-invasive techniques. Urinary EVs have been recognized as potential diagnostic biomarkers in renal disease [33]. The content of miR-24-3p in urinary extracellular vesicles from T2D patients with diabetic kidney diseases is higher than that in normal glucose tolerance T2D patients [34]. miR-24-3p may be a novel marker for the T2D patients with diabetic kidney diseases.

\subsection{Effects of $\mathrm{GA}, \mathrm{H}_{2} \mathrm{O}_{2}$, miR-24-3p siRNA on $\mathrm{Mg}^{2+}$ Influx}

So far, we reported that $\mathrm{Mg}^{2+}$ influx is suppressed by TRPM6 siRNA in NRK-52E cells, indicating that TRPM6 may be functionally expressed [35]. The addition of $5 \mathrm{mM} \mathrm{MgCl} 2$ in the extracellular solution induced the elevation of fluorescence intensity of Magnesium Green (Figure 4A), which means the elevation of $\left[\mathrm{Mg}^{2+}\right]_{i}$. This effect was suppressed by the treatment with GA, which was rescued by NAC. In addition, the elevation of $\left[\mathrm{Mg}^{2+}\right]_{i}$ was attenuated by $\mathrm{H}_{2} \mathrm{O}_{2}$. These results suggest that $\mathrm{Mg}^{2+}$ influx via TRPM6 is inhibited by oxidative stress. The treatment with miR-24-3p siRNA blocked the $\mathrm{H}_{2} \mathrm{O}_{2}$-induced reduction of $\mathrm{Mg}^{2+}$ influx (Figure 4B). These effects are similar to those in real-time PCR analysis. We suggest that GA suppresses the expression level of TRPM6 mediated by the elevation of ROS generation and miR-24-3p production, resulting in the inhibition of $\mathrm{Mg}^{2+}$ 
reabsorption in the renal tubular epithelial cells. miR-24-3p may be a novel target for hypomagnesemia therapy in T2D.

\section{A}
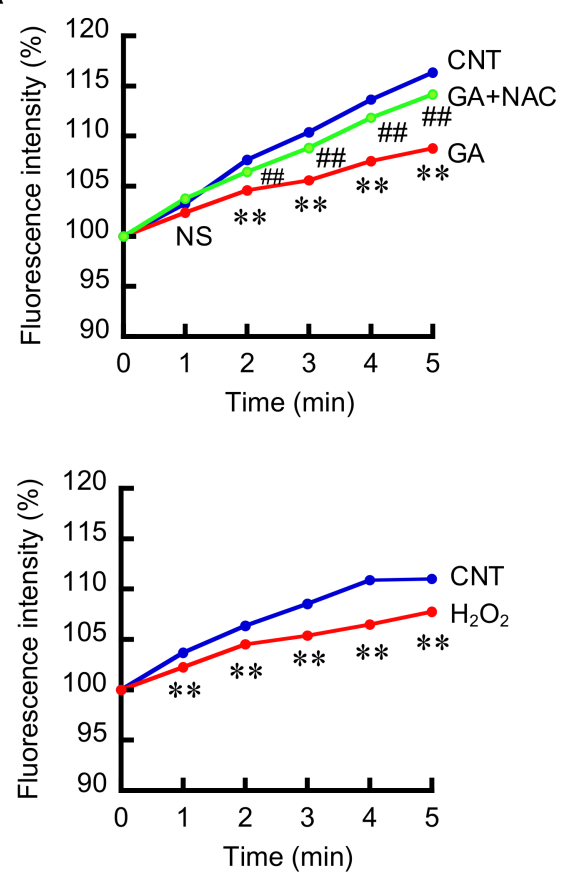

$\mathrm{B}$

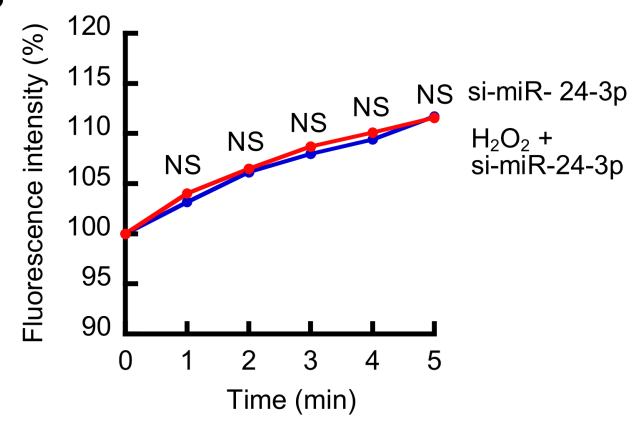

Figure 4. Effects of TRPM6 expression modulators on the elevation of $\left[\mathrm{Mg}^{2+}\right]_{\mathrm{i}}$. (A) NRK-52E cells were treated in the absence (CNT) or presence of $500 \mu \mathrm{g} / \mathrm{mL} \mathrm{GA}, 2 \mathrm{mM} \mathrm{NAC}$, and $50 \mu \mathrm{M} \mathrm{H}_{2} \mathrm{O}_{2}$ for $\left.24 \mathrm{~h} . \mathrm{Mgg}^{2+}\right]_{\mathrm{i}}$ was measured using a fluorescence microplate reader. The extracellular solution was changed to HBSS containing $5 \mathrm{mM} \mathrm{MgCl}_{2}$ at $0 \mathrm{~min}$. $\left[\mathrm{Mg}^{2+}\right]_{\mathrm{i}}$ was measured using a fluorescence microplate reader and represented as percentage of $0 \mathrm{~min}$. (B) The cells transfected with si-Neg or si-miR-24-3p were treated with $50 \mu \mathrm{M} \mathrm{H}_{2} \mathrm{O}_{2}$ for $24 \mathrm{~h}$. [ $\left.\mathrm{Mg}^{2+}\right]_{i}$ was represented as percentage of $0 \mathrm{~min}$. $n=5-6 .{ }^{* *} p<0.01$ compared with CNT. ${ }^{\#} p<0.01$ compared with GA. ${ }^{\text {NS }} p>0.05$ compared with CNT or si-miR-24-3p.

\section{Conclusions}

We found that the mRNA level of TRPM6 is decreased by GA and $\mathrm{H}_{2} \mathrm{O}_{2}$ in renal tubular NRK-52E cells. The $\mathrm{H}_{2} \mathrm{O}_{2}$-induced reduction of TRPM6 mRNA and $\mathrm{Mg}^{2+}$ influx was rescued by miR-24-3p siRNA. Our data indicate that GA may decrease TRPM6 expression mediated by the elevation of ROS and miR-24-3p in renal tubular epithelial cells of T2D. NRK-52E cells are thought to be a proximal tubular origin because they have similar characteristics including production of collagen and secretion of C-type natriuretic peptide to proximal tubular cells [36]. Therefore, we need further study to clarify whether miR-24-3p is involved in the reduction of TRPM6 expression in the DCT cells. 
Author Contributions: Investigation and analyzed the data, C.H., Y.T. and E.O. Writing-original draft preparation, A.I. Writing-review and editing, Y.Y., H.H. and T.M. Supervision, A.I. Project administration, A.I. Funding acquisition, A.I. All authors have read and agreed to the published version of the manuscript.

Funding: This work was supported in part by JSPS KAKENHI grant number $19 \mathrm{H} 03373$ and grants from the Kidney Foundation, Japan (Grant Number JKFB19-12), Public Foundation of Elizabeth Arnold-Fuji, Japan, and Iijima Tojuro Memorial Foundation, Japan (AI).

Institutional Review Board Statement: Not applicable.

Informed Consent Statement: Not applicable.

Data Availability Statement: Not applicable.

Conflicts of Interest: All authors declare they have no conflict of interest in the work.

\section{References}

1. Lowenstein, F.W.; Stanton, M.F. Serum magnesium levels in the United States, 1971-1974. J. Am. Coll. Nutr. 1986, 5, 399-414. [CrossRef] [PubMed]

2. Quamme, G.A.; de Rouffignac, C. Epithelial magnesium transport and regulation by the kidney. Front. Biosci. 2000, 5, D694-D711. [CrossRef]

3. Xi, Q.; Hoenderop, J.G.; Bindels, R.J. Regulation of magnesium reabsorption in DCT. Pflugers Arch. 2009, 458, 89-98. [CrossRef] [PubMed]

4. Stuiver, M.; Lainez, S.; Will, C.; Terryn, S.; Gunzel, D.; Debaix, H.; Sommer, K.; Kopplin, K.; Thumfart, J.; Kampik, N.B.; et al. $\mathrm{CNNM} 2$, encoding a basolateral protein required for renal $\mathrm{Mg}^{2+}$ handling, is mutated in dominant hypomagnesemia. Am. J. Hum. Genet. 2011, 88, 333-343. [CrossRef] [PubMed]

5. Sponder, G.; Mastrototaro, L.; Kurth, K.; Merolle, L.; Zhang, Z.; Abdulhanan, N.; Smorodchenko, A.; Wolf, K.; Fleig, A.; Penner, R.; et al. Human CNNM2 is not a Mg(2+) transporter per se. Pflugers Arch. 2016, 468, 1223-1240. [CrossRef] [PubMed]

6. de Leeuw, I.H.; van Gaal, L.; Vanroelen, W. Magnesium and obesity: Effects of treatment on magnesium and other parameters. Magnesium 1987, 6, 40-47.

7. Dousdampanis, P.; Trigka, K.; Fourtounas, C. Hypomagnesemia, chronic kidney disease and cardiovascular mortality: Pronounced association but unproven causation. Hemodial Int. 2014, 18, 730-739. [CrossRef] [PubMed]

8. Colditz, G.A.; Manson, J.E.; Stampfer, M.J.; Rosner, B.; Willett, W.C.; Speizer, F.E. Diet and risk of clinical diabetes in women. Am. J. Clin. Nutr. 1992, 55, 1018-1023. [CrossRef] [PubMed]

9. American Diabetes, A. Standards of medical care in diabetes-2013. Diabetes Care 2013, 36 (Suppl. 1), S11-S66. [CrossRef] [PubMed]

10. Rodriguez-Moran, M.; Guerrero-Romero, F. Oral magnesium supplementation improves insulin sensitivity and metabolic control in type 2 diabetic subjects: A randomized double-blind controlled trial. Diabetes Care 2003, 26, 1147-1152. [CrossRef] [PubMed]

11. Takayanagi, K.; Shimizu, T.; Tayama, Y.; Ikari, A.; Anzai, N.; Iwashita, T.; Asakura, J.; Hayashi, K.; Mitarai, T.; Hasegawa, H. Downregulation of transient receptor potential M6 channels as a cause of hypermagnesiuric hypomagnesemia in obese type 2 diabetic rats. Am. J. Physiol. Renal Physiol. 2015, 308, F1386-F1397. [CrossRef] [PubMed]

12. Ikari, A.; Okude, C.; Sawada, H.; Yamazaki, Y.; Sugatani, J.; Miwa, M. TRPM6 expression and cell proliferation are up-regulated by phosphorylation of ERK1/2 in renal epithelial cells. Biochem. Biophys. Res. Commun. 2008, 369, 1129-1133. [CrossRef] [PubMed]

13. Ikari, A.; Sanada, A.; Okude, C.; Sawada, H.; Yamazaki, Y.; Sugatani, J.; Miwa, M. Up-regulation of TRPM6 transcriptional activity by AP-1 in renal epithelial cells. J. Cell. Physiol. 2010, 222, 481-487. [CrossRef] [PubMed]

14. Furukawa, C.; Fujii, N.; Manabe, A.; Matsunaga, T.; Endo, S.; Hasegawa, H.; Ito, Y.; Yamaguchi, M.; Yamazaki, Y.; Ikari, A. Up-regulation of transient receptor potential melastatin 6 channel expression by tumor necrosis factor-alpha in the presence of epidermal growth factor receptor tyrosine kinase inhibitor. J. Cell. Physiol. 2017, 232, 2841-2850. [CrossRef]

15. Ledeganck, K.J.; Boulet, G.A.; Bogers, J.J.; Verpooten, G.A.; De Winter, B.Y. The TRPM6/EGF pathway is downregulated in a rat model of cisplatin nephrotoxicity. PLoS ONE 2013, 8, e57016. [CrossRef]

16. Miranda-Diaz, A.G.; Pazarin-Villasenor, L.; Yanowsky-Escatell, F.G.; Andrade-Sierra, J. Oxidative Stress in Diabetic Nephropathy with Early Chronic Kidney Disease. J. Diabetes Res. 2016, 2016, 7047238. [CrossRef]

17. Cao, G.; Lee, K.P.; van der Wijst, J.; de Graaf, M.; van der Kemp, A.; Bindels, R.J.; Hoenderop, J.G. Methionine sulfoxide reductase B1 (MsrB1) recovers TRPM6 channel activity during oxidative stress. J. Biol. Chem. 2010, 285, 26081-26087. [CrossRef] [PubMed]

18. Takashina, Y.; Manabe, A.; Hasegawa, H.; Matsunaga, T.; Endo, S.; Ikari, A. Sodium Citrate Increases Expression and Flux of $\mathrm{Mg}(2+)$ Transport Carriers Mediated by Activation of MEK/ERK/c-Fos Pathway in Renal Tubular Epithelial Cells. Nutrients 2018, 10, 1345. [CrossRef]

19. Ikari, A.; Sanada, A.; Sawada, H.; Okude, C.; Tonegawa, C.; Sugatani, J. Decrease in transient receptor potential melastatin 6 mRNA stability caused by rapamycin in renal tubular epithelial cells. Biochim. Biophys. Acta 2011, 1808, 1502-1508. [CrossRef] 
20. Schlingmann, K.P.; Weber, S.; Peters, M.; Niemann Nejsum, L.; Vitzthum, H.; Klingel, K.; Kratz, M.; Haddad, E.; Ristoff, E.; Dinour, D.; et al. Hypomagnesemia with secondary hypocalcemia is caused by mutations in TRPM6, a new member of the TRPM gene family. Nat. Genet. 2002, 31, 166-170. [CrossRef]

21. Takezawa, R.; Schmitz, C.; Demeuse, P.; Scharenberg, A.M.; Penner, R.; Fleig, A. Receptor-mediated regulation of the TRPM7 channel through its endogenous protein kinase domain. Proc. Natl. Acad. Sci. USA 2004, 101, 6009-6014. [CrossRef] [PubMed]

22. Song, G.; Han, P.; Sun, H.; Shao, M.; Yu, X.; Wang, W.; Wang, D.; Yi, W.; Ge, N.; Li, S.; et al. Astragaloside IV ameliorates early diabetic nephropathy by inhibition of MEK1/2-ERK1/2-RSK2 signaling in streptozotocin-induced diabetic mice. J. Int. Med. Res. 2018, 46, 2883-2897. [CrossRef] [PubMed]

23. Hirasawa, Y.; Matsui, Y.; Yamane, K.; Yabuki, S.Y.; Kawasaki, Y.; Toyoshi, T.; Kyuki, K.; Ito, M.; Sakai, T.; Nagamatsu, T. Pioglitazone improves obesity type diabetic nephropathy: Relation to the mitigation of renal oxidative reaction. Exp. Anim. 2008, 57, 423-432. [CrossRef]

24. Nair, A.V.; Hocher, B.; Verkaart, S.; van Zeeland, F.; Pfab, T.; Slowinski, T.; Chen, Y.P.; Schlingmann, K.P.; Schaller, A.; Gallati, S.; et al. Loss of insulin-induced activation of TRPM6 magnesium channels results in impaired glucose tolerance during pregnancy. Proc. Natl. Acad. Sci. USA 2012, 109, 11324-11329. [CrossRef] [PubMed]

25. Huerta, M.G.; Roemmich, J.N.; Kington, M.L.; Bovbjerg, V.E.; Weltman, A.L.; Holmes, V.F.; Patrie, J.T.; Rogol, A.D.; Nadler, J.L. Magnesium deficiency is associated with insulin resistance in obese children. Diabetes Care 2005, 28, 1175-1181. [CrossRef] [PubMed]

26. Nadler, J.L.; Buchanan, T.; Natarajan, R.; Antonipillai, I.; Bergman, R.; Rude, R. Magnesium deficiency produces insulin resistance and increased thromboxane synthesis. Hypertension 1993, 21, 1024-1029. [CrossRef]

27. Ishibashi, Y.; Matsui, T.; Takeuchi, M.; Yamagishi, S. Beneficial effects of metformin and irbesartan on advanced glycation end products (AGEs)-RAGE-induced proximal tubular cell injury. Pharmacol. Res. 2012, 65, 297-302. [CrossRef]

28. Fukami, K.; Yamagishi, S.; Ueda, S.; Okuda, S. Role of AGEs in diabetic nephropathy. Curr. Pharm. Des. 2008, 14, 946-952. [CrossRef]

29. Sebastian-delaCruz, M.; Gonzalez-Moro, I.; Olazagoitia-Garmendia, A.; Castellanos-Rubio, A.; Santin, I. The Role of lncRNAs in Gene Expression Regulation through mRNA Stabilization. Noncoding RNA 2021, 7, 3.

30. Xie, B.; Zhao, R.; Bai, B.; Wu, Y.; Xu, Y.; Lu, S.; Fang, Y.; Wang, Z.; Maswikiti, E.P.; Zhou, X.; et al. Identification of key tumorigenesisrelated genes and their microRNAs in colon cancer. Oncol. Rep. 2018, 40, 3551-3560.

31. Agarwal, V.; Bell, G.W.; Nam, J.W.; Bartel, D.P. Predicting effective microRNA target sites in mammalian mRNAs. eLife 2015, 4, e05005. [CrossRef] [PubMed]

32. Liu, H.; Wang, X.; Wang, Z.Y.; Li, L. Circ_0080425 inhibits cell proliferation and fibrosis in diabetic nephropathy via sponging miR-24-3p and targeting fibroblast growth factor 11. J. Cell. Physiol. 2020, 235, 4520-4529. [CrossRef] [PubMed]

33. Sun, I.O.; Lerman, L.O. Urinary Extracellular Vesicles as Biomarkers of Kidney Disease: From Diagnostics to Therapeutics. Diagnostics 2020, 10, 311. [CrossRef] [PubMed]

34. Prabu, P.; Rome, S.; Sathishkumar, C.; Gastebois, C.; Meugnier, E.; Mohan, V.; Balasubramanyam, M. MicroRNAs from urinary extracellular vesicles are non-invasive early biomarkers of diabetic nephropathy in type 2 diabetes patients with the 'Asian Indian phenotype'. Diabetes Metab. 2019, 45, 276-285. [CrossRef]

35. Ikari, A.; Okude, C.; Sawada, H.; Takahashi, T.; Sugatani, J.; Miwa, M. Down-regulation of TRPM6-mediated magnesium influx by cyclosporin A. Naunyn Schmiedebergs Arch. Pharmacol. 2008, 377, 333-343. [CrossRef]

36. Fan, J.M.; Ng, Y.Y.; Hill, P.A.; Nikolic-Paterson, D.J.; Mu, W.; Atkins, R.C.; Lan, H.Y. Transforming growth factor-beta regulates tubular epithelial-myofibroblast transdifferentiation in vitro. Kidney Int. 1999, 56, 1455-1467. [CrossRef] 